\title{
Dimorfismo sexual e \\ sexualidade - Uma 7 abordagem biológica )
}

Lília Maria de Azevedo Moreira*

Fábio Alexandre Ferreira Gusmão**

"Porque é que a natureza decidiu seguir um caminho diferente, atribuindo à maior parte dos grupos a via infinitamente mais perigosa $\mathrm{e}$ atormentada da sexualidade?"

Resumo: $\mathrm{O}$ trabalho apresenta uma revisão de aspectos evolutivos referentes ao dimorfismo sexual na natureza. É discutido o caráter adaptativo das diferenças sexuais, tendo em vista o processo de reprodução sexuada e sua contribuição para a diversidade genética. $\mathrm{O}$ dimorfismo sexual permite $o$ estabelecimento de relações elaboradas entre indivíduos da mesma espécie, como os comportamentos de corte e está associado à divisão de trabalho em espécies gregárias. $\mathrm{O}$ homem apresenta dimorfismo sexual relativamente pequeno, mas as diferenças sexuais tem sido historicamente associadas à comportamentos sociais de subordinação e dominação.

Palavras chave: Sexualidade, Dimorfismo Sexual, Papéis Sexuais.

* Mestre e Doutora em Genética, Laboratório de Genético Humano e Citogenética - Universidade Federal da Bahia/UFBA.

** Graduando em Ciências Biológicas - Universidade Federal da Bahia/UFBA.

Recebido em 01.03 .00 Aprovado em 10.03 .00 
A história da vida provavelmente se iniciou há cerca de 3,5 bilhões e anos, com as primeiras células capazes de se manter e reproduzir. A conquista da Terra processou-se gradualmente e, há cerca de 1,5 bilhões de anos, registros seres unicelulares com estratégias de reprodução sexuada. Antes que se instalasse este mecanismo, as eventuais variações entre o indivíduo decorriam de mutações ocasionais e pouco freqüentes.

A reprodução sexuada é uma fonte de variabilidade genética que garante a continuidade do indivíduo, ao mesmo tempo que promove a evolução da espécie. Os ciclos sexuais compreendem uma alternância entre divisão cromossômica reducional (meiose), com formação de gametas haplóides e, união destes gametas pela fecundação, possibilitando a recombinação genética.

A fauna edicariana, com representantes de fios artrópodes, celenterados, espongiários e anelídeos, encontrados em rochas com mais de $700 \mathrm{mi}-$ lhões de anos, com órgãos, tecidos e mecanismos meióticos plenamente desenvolvidos, mostra que a sexualidade, tanto procariótica como meiótica, apresenta-se desde épocas antigas, intrinsecamente ligada à história da vida. A diversidade da vida atingiu a expansão que hoje se observa porque a natureza fez desabrochar a sexualidade entre os seres vivos. No sentido biológico, a sexualidade pode ser entendida como um conjunto de estratégias da natureza que facilitam a recombinação genética entre indivíduos da mesma espécie.

Assim, em formas primitivas de vida como certas bactérias que embora não possuam cicios sexuais apresentam mecanismos parasexuais, já se verifica a existência de dimorfismo sexual, com tipos capazes de conjugarse. As bactérias doadoras "machos" apresentam epissomo (pequena molécula de DNA) que pode ocorrer livre $\left(\mathrm{F}^{+}\right)$ou ligado ao cromossomo bacteriano (Hfr) enquanto que as bactérias "fêmeas", sem este fator denominam-se $\mathrm{F}$. Na conjugação o DNA de bactérias doadoras $\left(\mathrm{F}^{+}, \mathrm{F}^{\prime}, \mathrm{Hfr}\right)$ penetra na $\mathrm{F}^{\text {- }}$ através da formação de pili ou "pêlos sexuais". Na ausência destas estruturas, bactérias contendo DNA com replicarão independente são incapazes de transferir seu DNA.

Em organismos como Drosophila melanogaster, Caenorhabdits elegans e alguns ratos, a determinação do sexo gera indivíduos sexualmente dimórficos quanto à diversas características morfológicas e fisiológicas. Nos nematódeos, animais XX são normalmente hermafroditas e os XO, machos. Os hermafroditas são essencialmente fêmeas somáticas que podem inicialmente produzir espermatozóides e depois óvulos. $\mathrm{Na}$ Drosophila, moscas XX são fêmeas e XY machos, apesar do Y não determinar o sexo. Em ambos grupos os sexo somático é determinado pela razão de cromossomos $\mathrm{X}$ em relação aos autossomos (razão X:A), controlada por uma cascata hierárquica de genes (McElreavey et al, 1993).

Os vertebrados são dióicos - compreendem machos e fêmeas, que recebem esta designação de acordo com os gametas que produzem espermatozóides e óvulos, respectivamente. Nos gametas, o número de cromossomos (elementos celulares portadores dos genes) é reduzido à me- 
tade, com um representante de cada par. Com a fecundação, a união dos gametas restabelece o número diplóide (2n) e surgem numerosas combinações genéticas que são selecionadas de acordo com o seu valor adaptativo.

Os cromossomos diferentes nos dois sexos denominam-se cromossomos sexuais, gonossomos ou heterocromossomos, enquanto que os demais são chamados autossomos. O dimorfismo dos cromossomos sexuais apresenta variações na escala dos vertebrados: enquanto nas salamandras e pássaros as fêmeas constituem o sexo heterogaméticos, nas rãs e mamíferos são os machos os heterogaméticos. Na espécie humana, o homem apresenta 22 pares de autossomos e 1 par de gonossomos - X e Y $(2 n=46)$; a mulher também possui 23 pares de cromossomos, mas os dois gonossomos são iguais $-\mathrm{XX}$.

As espécies dióicas possuem ao menos um gene responsável pela determinação do sexo. Nos mamíferos a determinação do sexo significa determinação testicular. O principal gene responsável pela formação do testículo (TDF: Testis Determining Factor) foi identificado por Goodfellow e colaboradores (Sinclair et al, 1990). Trata-se do gene SRY (sexual reverse) que compreende cerca de $0,2 \%$ do cromossomo Y, necessário para a indução da diferenciação sexual masculina na gonada embrionária bipotente de mamíferos levando a formação testicular. Koopman et al (1991) demostraram que ratos cromossomicamente fêmeas, transgênicos para fragmento de $14,5 \mathrm{~Kb}$ do gene Sry, equivalente ao SRY humano, desenvolviam fenótipo masculino normal embora estéril, oferecendo prova conclusiva da ação principal deste gene. Este fato não exclui a existência de outros genes, de natureza autossômica, intervenientes neste processo (McElreavey et al, 1993).

A presença de duas categorias de indivíduos produtores de gametas, favorece a diversidade genética e traz inúmeras possibilidades de adaptação e conquista do ambiente. $\mathrm{O}$ dimorfismo sexual permite o estabelecimento de relações elaboradas entre indivíduos da mesma espécie, através de características fisiológicas, morfológicas e comportamentais. A periodicidade dos cicios sexuais, odores, características da genitália externa, os cantos, danças, cortejos aproximam machos e fêmeas e contribuem para o acasalamento entre pares da mesma espécie.

A ocorrência de machos e fêmeas, diferentes entre si, é mais freqüente entre animais, embora se observe em alguns vegetais. Em certos casos, as diferenças entre os sexos são de tal ordem que macho e fêmea não parecem pertencer à mesma espécie. Assim, na Bonellia viridis, verme marinho, formas jovens diferenciam-se em machos ou fêmeas, conforme a existência de contacto com substâncias do corpo da fêmea adulta. Vermes jovens desenvolvidos livres, originam fêmeas com cerca de $1 \mathrm{~m}$ de comprimento enquanto que outros, se fixam na tromba de uma fêmea adulta por cerca de 3 a 4 dias e se diferenciam como machos, migrando para o aparelho reprodutor feminino, onde vivem como parasitas nos canais genitais, com os órgãos do corpo degenerados, exceto os do aparelho reprodutor. Quando larvas fixa- 
das na tromba da fêmea, são desligados antes da conclusão de sua diferenciação masculina, prosseguem sua evolução para o sentido feminino.

O processo de reprodução sexuada, evolui no sentido de desenvolverem-se genitais internos e órgãos efetores externos. A fecundação também passa gradualmente de externa (como em peixes), para interna, trazendo consequentemente o desenvolvimento protegido do embrião. Nos organismos que produzem ovos amniotas (répteis, aves e mamíferos monotremos), a fecundação é interna e a casca formada após a fertilização, protege o embrião e as suas membranas durante o desenvolvimento. Nos marsupiais placentados e mamíferos, a fecundação é interna e o embrião desenvolve-se dentro da mãe, sendo por ela nutrido.

Entre os répteis primitivos, o acasalamento realiza-se pela simples junção dos lábios cloacais, como ocorre na maioria das aves. O aperfeiçoamento da cópula, com a introdução dos órgãos condutores dos gametas, são observados nas tartarugas e crocodilos. Nestes répteis, um tubérculo da parede cloacal é transformado no adulto em órgão copulador, o pênis, que em repouso encontra-se retraído na cloaca. Entre os répteis e mamíferos, há uma grande novidade na forma do pênis: nos lagartos e serpentes, este é duplo (hemipenis) e ornamentado com filas de espinhos córneos que possivelmente estimulam os receptores nervosos, nas vias genitais das fêmeas. Os mamíferos não apresentam os ornamentos observados no hemipenis de certos répteis, entretanto mostram variações na forma da glande que no homem é arredondada; nos cães e gatos é ponteagudo, em alguns ruminantes mostra a forma de hélice e na Anta (Tapirus terrestris), apresenta-se como um tampão (Gasc, 1981). Esta variabilidade pode apresentar significado na preservação das espécies, uma vez que facilita o reconhecimento e o ajuste dos pares e com isto, favorece a fecundação intraespecífica.

Estabelecendo um paralelo entre a evolução dos genitais nos dois sexos, verifica-se que nos machos há um aperfeiçoamento maior a nível da genitália externa, produzindo maior eficácia na condução dos gametas, enquanto que nas fêmeas, a genitália interna é a mais modificada, protegendo o desenvolvimento da cria no seu interior.

Na espécie humana, a comparação entre os genitais externos mostra que no macho, o desenvolvimento embrionário da genitália indiferenciada com crescimento e fechamento de pregas primordiais, origina o pênis, e as bolsas escrotais, correspondentes ao clitóris, pequenos e grandes lábios da fêmea.

No homem e outros mamíferos, os testículos deixam a posição abdominal para localizarem-se nas bolsas escrotais. Esta posição, além de proporcionar temperaturas mais baixas às células germinativas, parece conferir ao órgão copulador papel de atributo masculino, culturalmente valorizado.

A grande maioria dos macacos e chimpanzés apresentam modificações na genitália externa e na pele sexual (região em tomo da genitália externa) que influenciam o comportamento social. Nestes primatas, quanto mais é o dimorfismo sexual, maior o domínio que o chefe oferece. 
No cicio menstrual dos babuínos, chimpanzés e gorilas há aumento e descoloração da pele sexual na fase estro, o que não é observado no homem e nos gibões. Nestes, observam-se algumas das pré-condições para o estabelecimento da família permanente composta do macho, fêmea, 2 ou 3 filhos e o uso da voz para manter os membros do grupo juntos e delimitar a propriedade. Também no gibão, o menor dimorfismo sexual corresponde uma posição de menor domínio do macho.

$\mathrm{Na}$ espécie humana, o acesso aos meios contraceptivos, possibilita ao homem e à mulher assumir o controle da sua fertilidade e transmissão do seu patrimônio genético. $\mathrm{O}$ dimorfismo sexual é relativamente pequeno e as relações sociais são mantidas por cooperação e divisão de tarefas.

Na sociedade ocidental as diferenças sexuais tem sido historicamente associadas à comportamentos sociais de dominação e subordinação que são designados como papéis sexuais. Estudos antropológicos mostram que estas atribuições não correspondem a quaisquer determinações biológicas. Assim, Margareth Mead (1969) relata diferenças de temperamentos entre membros de três sociedades primitivas de Nova Guiné e observa que nos Tchambuli os papéis masculinos e femininos são praticamente contrários aos papéis definidos nas sociedades ocidental. Embora esses papéis sejam peculiares nas diversas culturas, em nenhuma sociedade existe um limite absoluto de comportamento.

No presente, ocorrem realidades heterogêneas, desde a extrema desvalorização do sexo feminino em sociedades islâmicas fundamentalistas e a casos de infanticídio de crianças do sexo feminino na China, à uma posição geralmente inferiorizada deste gênero na maioria das sociedades.

\section{REFERÊNCIAS BIBLIOGRÁFICAS}

GASC, J. P. J. A aventura prodigiosa do nosso corpo. Trad. Pedro Jordão, Lisboa, Edições 70 Ltda., 1981, 236p.

McELREAVEY, K.; VILAN, E.; COTINOT, C.; PAYEN, E.; FELLOWS, M. Control of Sex determination in animals. Eur. J. Biochem. v. 218, p. 769-783, 1993.

MEAD, M. Sexo e temperamento. São Paulo, Perspectiva, 1969.

KOOPMAN, P.; GUBBAY, J.; VIVIAN, N.; GOODFELOW, P. N.; LOVELLBADGE, R. Male deveiopment of chromosomaly male mice transgenic for Sry. Nature v. 351, p. 117-121, 1997.

SINCLAIR, A. H.; BERTA, P.; PALMER, M. S.; HAWKINS, J. R.; GRIFFITHS, B. L.; SMITH, M. J.; FOSTER, J. M.; FRISCHAUF, A. M.; LOVELLBADGE, R.; GOODFELOW, P. N. A gene from the human sexdetermination region encodes a protein with similarity to a conserved DNA binding motif. Nature v. 346. p. 240-244, 1990. 